\title{
Notes
}

\section{Aliens' Right to Teach: Political Socialization and the Public Schools}

In recent years, aliens ${ }^{1}$ have made great strides against state-imposed employment discrimination. ${ }^{2}$ Some commentators read recent Supreme Court opinions in Sugarman v. Dougall ${ }^{3}$ and In re Griffiths ${ }^{4}$ as invalidating virtually all state laws that require United States citizenship as a prerequisite to employment. ${ }^{5}$ Nonetheless, many states still bar aliens from teaching in public elementary and secondary schools.

This Note analyzes the constitutionality of state-imposed restrictions on the employment of alien teachers. It argues that Sugarman and Griffiths, while greatly limiting the scope of permissible discrimination against aliens, recognize an excepted area for jobs which have a critical relationship to the identity and legitimacy of the political community. Public school teaching might fit within this area of allow-

1. All references are to permanent resident aliens. An alien is "any person not a citizen or national of the United States." 8 U.S.C. $\$ 1101(a)(3)$ (1970). To acquire permanent residence, an alien must possess an immigrant visa and thus have "been lawfully accorded the privilege of residing permanently in the United States as an immigrant in accordance with the immigration laws ..." 8 U.S.C. $\$ 1101$ (a)(20) (1970). Virtually all aliens permitted to be employed for an indefinite time have permanent residence status. The only other aliens legally permitted to work in the United States do so on a temporary basis. These persons are designated "nonimmigrant" aliens. 8 U.S.C. $\$ 1101(a)(15)(1970)$. Telephone interview with Ralph Farb, Deputy General Counsel, Immigration and Naturalization Service, Wash., D.C., Sept. 12, 1975.

2. The extent to which state and local law has restricted the employment opportunities of aliens can be seen in the limitations only recently invalidated. Taggart v. Mandel, 391 F. Supp. 733 (D. Md. 1975) (state statute making citizenship a prercquisite to licensing as a notary public); Sundram v. City of Niagara Falls, 77 Misc. 2d 1002, 357 N.Y.S.2d 943 (Sup. Ct., Niagara Co. 1973) (city ordinance making citizenship a prerequisite to licensing as a taxi cab driver); Examining Bd. of Eng'rs, Architects \& Surveyors v. Flores De Otero, No. $74-520$ (D.P.R., Dec. 19, 1974), prob. juris. noted, 95 S. Ct. 1988 (1975) (Puerto Rico statute requiring that applicants be citizens in order to be granted full licenses as engineers, architects or surveyors). The Supreme Court is presently considering whether the federal civil service can cxclude aliens. Mow Sun Wong v. Hampton, 500 F.2d 1031 (9th Cir.), cert. granted, 417 U.S. 944 (1974).

For a discussion of the full scope of these laws, see M. Konvitz, The Alien ANd THE AsIatic in AMERICAN LAw (1946); Note, Constitutionality of Restrictions on Aliens' Right to Work, 57 Colum. L. Rev. 1012 (1957); Note, Protection of Alien Rights Under the Fourteenth Amendment, 1971 Duke L.J. 583; Comment, Aliens, Employment, and Equal Protection, 19 Vill. L. REv. 589, 590-95 (1974).

3. 413 U.S. 634 (1973).

4. 413 U.S. 717 (1973).

5. See Das, Discrimination in Employment Against Aliens-The Impact of the Constitution and Federal Civil Rights Law, 35 U. PITr. L. REv. 499 (1974); Comment, supra note 2, at 590 . 
able discrimination if the state has an interest in using its public schools for such a critical political function-in particular, the education of students for participation in the political community. The necessary assessment is whether the nature of a teacher's role in the process of political socialization creates a substantial state interest which could justify denying teacher certification on the basis of alienage. The Note concludes that the states do have some legitimate interest in the process of political socialization in the public schools. But because of First Amendment considerations and the imprecision of the certification laws in their present form, this interest is insufficient to validate current state laws discriminating against alien teachers.

\section{Alienage and Equal Protection}

The right of the states to provide for and regulate public education has long been recognized. ${ }^{6}$ As part of this responsibility, all of the states supervise the licensing of teachers in the public schools. ${ }^{7}$ Twentyone states use United States citizenship as a qualification for certification as a public school teacher, ${ }^{8}$ thus restricting an alien's opportunity to teach.

Two main types of restrictions are imposed. ${ }^{9}$ In six states, a resident alien is unable to secure a permanent license to teach whether or not he or she plans to be naturalized. ${ }^{10}$ In 12 other states, an alien may

6. See, e.g., Epperson v. Arkansas, 393 U.S. 97, 104 (1968) (dictum); Pierce v. Society of Sisters, 268 U.S. 510, 534 (1925) (dictum); Myers v. Nebraska, 262 U.S. 390, 402 (1922) (dictum). Most states have constitutional provisions requiring that the state legislature create a system of public education. See A. Morris, Tine Constitution ANd AMERican EDvcition 113 (1974).

7. All 50 states require that a teacher be certified before teaching in a public school. See T. Stinnetr, A Matidal on Standards Affecting Schoor Personnel in the United Srates 3 (Nat'l Educ. Ass'n 1974). In addition, 29 states require certification of some teaching personnel in private, parochial, or independent schools. See id. at 3, 10 . Unless otherwise noted, all references below are to certification requirements for public school teachers only.

For purposes of equal protection analysis, discrimination against aliens in the employment of public school teachers constitutes state action by virtuc both of the state-imposed certification requirements and the public character of the municipality or school district providing the employment. Although this Note will focus on the mandatory certification requirements, the analysis would apply equally to any local policy to pass over aliens in hiring teachers.

8. The number of states requiring citizenship for certification has declined by onethird in the last eight years. (In 1967 the number was 32.) See T. Stinnetr, A Maivat. on Certificition Requirements for School Personnel in the United Stites 28 (Nat'l Educ. Iss'n 1970). In many states, the state board of education is authorized to sct requirements for certification. Id. at 31. Thus, restrictions on aliens' right to teach arc imposed both by statute and by the regulations issued by state departments of education.

9. The following survey of types of citizenship requirements was completed in Felsuary, 1975.

10. Rfoulitions of Cons. State Agencies $\$$ 10-146-2(d) (1971); Mississippi (sce T. 
be certified provisionally upon declaring his or her intent to become a citizen. ${ }^{11}$ Cutting across these categories, in 10 states an alien can be certified when participating in a federal or state exchange program. ${ }^{12}$ In addition, four states will grant a temporary certificate at the request of a school principal or other official who is willing to employ an alien. ${ }^{13}$

The Supreme Court recognized in $\mathbf{1 8 8 6}$ that the equal protection clause extends to aliens. ${ }^{14}$ Nevertheless, because of the courts' use of the rational relation standard ${ }^{15}$ and acceptance of the states' asserted

Stinnetr, supra note 7, at 24); Mont. Rev. Cones ANN. $\$ 75-6004$ (1971); Nev. Rev. Stat. \$ 391.060 (1965); South Carolina (see T. Srinnetr, supra at 24); cf. Rhode Island Requirements for Certification (on file with Yale Law Journal) (if an alien lacks citizenship only because he or she has resided in the United States for too short a period to be eligible for naturalization, the citizenship requirement may be waived).

11. IDAHo CODE \$ 33-1202(4) (1963); ILL. ANN. STAT. ch. 122, \$ 21-1 (Smith-Hurd 1972); Mass. Gen. Laws ANn. ch. 71, $\$ 38 G$ (1974); Mich. Comp. Laws ANN. $\$ 340.852$ (1975); N.J. REv. STAT. $\$ 6.11-3.10$ (1970) (including an exception for foreign language teachers who have not declared their intention of becoming citizens and who have resided in the United States for less than 10 years); N.Y. Envc. LAw $\$ \$ 3001,3001-a$ (McKinney Supp. 1974); N.D. CeNT. Code \$ 15-36-07 (1971); Dep'T of EduC., OKLA, Teacher Education, Certification and Assignment Handbook 56 (1971) (on file with Yale Law Journal) (hereinafter cited as OrLahoma Certification Handbook); Texas Educ. CODE $\$ 13.044$ (1972); WASH. Rev. Code ANN. \$28A.67.020 (1970); W. VA. Code ANN. \$ 18A-3-1 (1971); Wyoming (see T. STINNETT, supra note 7, at 24).

12. Regs. of Conn. State Agencies \$ 10-146-2(d) (1971); Fla. Stat. ANn. \$ 231.17(2) (Supp. 1974); IdAho Code § 33-1202(4) (1963); Ill. ANN. Stat. ch. 122, § 2I-I (SmithHurd Supp. 1975); Mrch. Comp. Laws ANN. \$ 340.852 (Supp. 1975); Mont. Rev. Codes ANN. $\$ 75-6005$ (Supp. 1975); Nev. Rev. Stat. $\$ 391.070$ (1968); OKL.Ahoma Certification HandBOoK, supra note 11, at 56; WASH. REv. CODE ANN. $\$ 28 A .67 .020$ (1970); W. VA. Code INN. $\S 18 \mathrm{~A}-3-1(1971)$.

8 U.S.C. $\$ 1101(a)(15)(J)(1970)$ authorizes a nonimmigrant alien to work temporarily in the United States if he or she is part of an exchange program. This applies to any alien

having a residence in a foreign country which he has no intention of abandoning who is a bona fide student, scholar, trainec, teacher, professor, research assistant, specialist, or leader in a field of specialized knowledge or skill, or other person of similar description, who is coming temporarily to the United States as a participant in a program designated by the Secretary of State, for the purpose of teaching, instructing or lecturing, studying, observing, conducting research, consulting, demonstrating special skills, or receiving training ....

13. Regs. of ConN. State Agencies \$ 10-146-2(d) (1971); Mont. Rev. Codes ANN. \$ 756005 (1971); N.D. CENT. CodE \$ 15-36-11 (Supp. 1973); letter to Lon S. Babby from W.H. Jones, Director, Div. of Teacher Educ., State Dep't of Educ., Va., Dec. 24, 1974 (on file with Yale Law Journal).

There are two states that do not fit any of the categorics above. In Floricla, an alién may be certified if his or her services are needed and he or she takes an oath of allegiance. FLA. STAT. ANN. $\$ 231.17(1)$, (2), (3) (1974). In South Dakota, any alien who meets the usual qualifications may be temporarily certified. S.D. Regs. (on filc with Yale Law Journal).

14. Yick Wo v. Hopkins, 118 U.S. 356 (1886) (invalidating refusal of San Francisco board of supervisors to grant licenses for operation of laundries to Chinese residents of the city).

15. See Note, Prolection of Alien Rights Under the Fourteenth Amendment, supra note 2, at 588; Comment, supra note 2, at 590-99. The Supreme Court has traditionally used a two-tier approach in evaluating claims that a state statute violates the cqual 
interest in preserving jobs for their own citizens, ${ }^{16}$ the early successes of aliens in opposing employment discrimination were few and far between. ${ }^{17}$ In 1971, the Supreme Court stated in Graham v. Richard-

protection clause of the Fourteenth Amendment. See Gunther, Foreword: In Search of Evolving Doctrine On A Changing Court: $A$ Model for a Newer Equal Protection, 86 Harv. L. Rev. 1, 8 (1972). Under the "rational relation" test, a state must demonstrate that the challenged classification rests on grounds reasonably related to the advancement of a permissible objective. Developments in the Late-Equal Protection, 82 HArv. L. Rev. 1065, 1079 (1969). See McGowan v. Maryland, 366 U.S. 420, 425 (1961) ("It]he constitutional safeguard is offended only if the classification rests on grounds wholly irrelevant to the achievement of the State's objective"). However, a classification based upon a "suspect" criterion invokes a more stringent level of judicial review. (This more stringent standard of protection is also invoked when a classification touches upon a fundamental interest.) The operative effect of declaring a classification suspect is that the state must bear the "heavy burden" of showing a "compelling" interest to justify the law. Loving v. Virginia, 388 U.S. 1, 9 (1967). See Developments in the LawEqual Protection, supra at 1087-1120. In addition, the state must demonstrate that the classification adrances the interest with precision.

The "precision" of a classification is the manner in which it relates to the purpose of the law. Essentially the question is "whether all and only those persons similarly situated with respect to the purpese of the law" are treated equally by the classification. $I d$. at 1082. A classification may be underinclusive in that it does not include within the class all persons similarly situated. Alternatively, it may be overinclusive in that it includes persons who are not similarly situated with respect to the purpose of the law. Quite often a classification is both overinclusive and underinclusive. See Tussman \& tenBroek, The Equal Protection of the Laws, 37 C.sL. L. REv. 341 (1949). A perfect classification is virtually impossible to attain. However, the degree of allowable imperfection varies with the criterion of classification. When a suspect category is involved, the courts will tolerate less variance from a perfect classification and may demand that "less drastic means" be used to achieve the statutory purpose. See Gunther, supra at 21.

16. In the past, the states have tried to justify restriction of alien employment by pointing to a "special public interest" in preserving jobs for state citizens. Heim v. McCall, 239 U.S. 175 (1915); Truax v. Raich, 239 U.S. 33, 39.40 (1915); Rok v. Legg, 27 F. Supp. 243, 245 (S.D. Cal. 1939). See Note, Constitutionality of Restrictions on Aliens" Right to Work, supra note 2, at 1016-18. The rationale was best articulated by Judge Cardozo in People v. Crane, 214 N.Y. 154, 108 N.E. 427, aff'd sub nom. Crane v. New York, 239 U.S. 195 (1915):

To disqualify aliens is discrimination indeed, but not arbitrary discrimination, for the principle of exclusion is the restriction of the resources of the state to the advancement and profit of the members of the state. ...

Id. at 161,108 N.E. at 429 .

The state in determining what use shall be made of its own moneys, may legitimately consult the welfare of its own citizens rather than that of aliens. Whatever is a privilege rather than a right, may be made dependent upon citizenship. In its war against poverty, the state is not required to dedicate its own resources to citizens and aliens alike.

Id. at 164,108 N.E. at 430 .

17. In Truax v. Raich, 239 U.S. 33 (1915), the Court invalidated a state statute which required that 80 percent of the employees in any business be U.S. citizens. The Court stated that "the right to work for a living in the common occupations of the community is of the very essence of the personal freedom and opportunity that it was the purpose of the [14th] Amendment to secure." Id. at 41. The decision was based both on equal protection and on the exclusive constitutional authority of the federal government to regulate immigration and naturalization. See note 18 infra.

In Takahashi v. Fish \& Game Comm'n, 334 U.S. 410 (1948), the Court rejected the restriction of commercial fishing licenses to citizens. Again the decision was grounded on both the equal protection clause and the federal government's preemptive regulation of immigration and naturalization. 
son that classifications based on alienage were "suspect,"1s and also rejected the "special public interest" of a state in preserving jobs for its citizens. ${ }^{19}$ In so ruling, the Court paved the way for the two decisions that have greatly narrowed the allowable area of restrictions on alien employment.

\section{A. Sugarman v. Dougall: The Excepted Area}

In 1973, in Sugarman v. Dougall, ${ }^{20}$ the Supreme Court considered an equal protection challenge to a provision of New York State's civil service law excluding aliens from jobs classified as "competitive." 21 The state asserted a substantial interest in guaranteeing that a civil servant who " "participates directly in the formulation and execution of government policy" "22 be unimpaired in the fulfillment of

18. Graham v. Richardson, 403 U.S. $365,371-72$ (1971) (footnotes omitted):

[T]he Court's decisions have established that classifications based on alienage, like those based on nationality or race, are inherently suspect and subject to close judicial scrutiny. Aliens as a class are a prime example of a "discrete and insular" minority ... for whom such heightened judicial solicitude is appropriate.

Despite the Graham declaration, alienage may be distinguished from race as a suspect category. First, alienage is not an "unalterable trait." Rather, it is a "governmentally created status" from which a permanent resident alien can remove himself voluntarily by applying for naturalization. (Once an alien has secured an immigrant visa and thus has qualified for permanent residency, there are no further numerical quotas to limit his or her chances for naturalization.) See Lindsey v. Normet, 405 U.S. 56, 73 (1972) (dictum that earlier cases invoked strict scrutiny where "certain classifications based on unalterable traits such as race and lineage" were used); Diaz v. Weinberger, 361 F. Supp. 1, 8 (S.D. Fla. 1973) ("the fact that alienage is a governmentally created status suggests that it may not constitute such a consistently illegitimate distinction as to warrant mechanical application of the compelling interest test").

Second, alienage is a political status subject to Congress's power to regulate naturalization and immigration. U.S. ConsT, art. $I, \S 8, \mathrm{cl} .4$ : "The Congress shall have Power ... To establish an uniform Rule of Naturalization ...."Though many alienage cases have turned on an equal protection/suspectness analysis, always remaining in the background is the possibility that a disability accorded aliens by the federal government will be sustained by virtue of federal power to regulate naturalization and immigration and that a disability accorded aliens by a state will be voided by virtue of its interference with that exclusive federal power. But see note 37 infra.

19. 403 U.S. $365,374-76(1971)$. The Court gave several reasons for rejecting the "special public interest" rationale. For one, it was based on a right/privilege distinction that was no longer viable. Second, the state's concern with limiting expenditures was not sufficiently compelling. Third, the state could have no "special interest" in tax revenues to which the alien also contributed. The rationale was under attack for many years before Graham; indeed it was originally undermined by Takahashi v. Fish \& Game Comm'n, 334 U.S. $410,420-21$ (1948).

20. 413 U.S. 634 (1973).

21. At the time of the action, New York civil service employees were divided into "classified" and "unclassified" positions. Of the four categories of classified positions, only the competitive class (filled on the basis of a competitive examination) required citizenship. The other categories of classified civil service (including upper echelon positions in the state executive, municipal and judicial departments) and the unclassified service (including elective offices, executive and legislative appointments, and teaching positions) did not require citizenship. $I d$. at 639-40.

22. Id. at 641 (quoting from appellants' brief). 
his duties by allegiance to a foreign government. Though the Court proceeded to hold that the provision excluding aliens was too imprecise, ${ }^{23}$ it did not wholly reject the premise of the state's argument. Rather the Court accepted that there was some limited area of employment for which citizenship constitutionally could be required.24

The guidelines provided by the Court to describe this "excepted area" were put in terms which, though ambiguous, may be broad reaching. The Court noted the states' interest in preserving " 'the basic conception of a political community' "'s and suggested that citizenship as a qualification was permissible not only for voters, but for elective positions and "important nonelective executive, legislative, and judicial positions ...."28 The Court reasoned that incumbents of such positions are "officers who participate directly in the formulation, execution, or review of broad public policy" and thus "perform functions that go to the heart of representative government."'27

Sugarman did not make clear whether aliens may be flatly excluded from some positions of state or municipal employment which cannot be categorized as "offices" 28 and which do not involve the formulation

23. Id. at 642-43. In view of the proffered justification, the restriction was both underinclusive and overinclusive. It was underinclusive because it did not require citizenship for the upper-level jobs in the classified and unclassified civil service where citizenship was arguably essential to effective performance. Similarly the restriction was overinclusive because it indiscriminately excluded aliens from jobs far removed from the formulation and execution of governmental policy, such as sanitation workers and typists. Id. at 643 .

24. Id. at 646-47. Despite the diffident wording of the last section of Sugarman ("Neither do we hold that a State may not, in an appropriately defined class of positions, require citizenship . . . 413 U.S. at 647), the Court's description of the excepted area was not really dicta. Rather it was critical to the Court's holding that the New York civil service statute excluding aliens was underinclusive. See id. at 642-43.

25. Id. at 647, quoting Dunn v. Blumstein, 405 U.S. 330, 344 (1972). See 413 U.S. at $642-43$ (citation omitted):

We recognize a State's interest in establishing its own form of government, and in limiting participation in that government to those who are within "the basic conception of a political community." . . . We recognize, too, the State's broad power to define its political community. But in seeking to achieve this substantial purpose, with discrimination against aliens, the means the State employs must be precisely drawn in light of the acknowledged purpose.

26. 413 U.S. at 647 (emphasis added).

27. Id. (emphasis added).

28. Which nonelective positions constitute offices under state law varies considerably from state to state. Among the characteristics considered in determining whether a position is an office or employment are (1) the delegation of sovereign powers; (2) participation in important policymaking and decisionmaking in the governmental unit; (3) the requirement of an official oath and official bond; and (4) appointment for a definite term, with authority conferred by law. See E. McQuillin, The Law of MuniciPAL Corporitions $\$ 12.30$ (rev. 3d ed. 1973). The lack of any clear standard for determining who is an "officer" and who is a mere "employee" is a strong reason for not reading Sugarman's reference to "officers" as exhausting all permissible areas of discrimination.

Teachers are generally considered to be employees rather than officers. See cases citcd 
of high-level policy. However, Sugarman's emphasis on the state's substantial interest in defining and preserving a political community does suggest that exclusion is permissible when the position is, in some sense, essential to preserving the identity of the political community. The Court's explicit exception for "officers" may fairly be read as a consequence of this underlying concern; the excepted area thus might also include other jobs having a critical relationship to the preservation of the political community, even if those jobs cannot be classified as "offices." 20

\section{B. In re Griffiths}

In re Griffiths, ${ }^{30}$ decided the same day as Sugarman, may seem to narrow the excepted area of employment for which citizenship is a permissible state-imposed qualification. The case concerned the exclusion of an alien, a Netherlands woman named Fre Le Poole Griffiths, from admission to the bar in Connecticut. ${ }^{31}$ In an effort to meet the " "heavy burden' "32 required to justify a classification based on alienage, the Connecticut Bar Examining Committee pointed to the attorney's role as an officer of the court. The Court in turn recognized the state's interest in ensuring that licensed attorneys be qualified, but concluded that an attorney's powers, whether to sign writs or take depositions, "hardly involve matters of state policy or acts of such unique responsibility as to entrust them only to citizens." 33 The Court in Griffiths also refused to hold that the mere licensing of a lawyer by the state was sufficient to place him "so close to the core of the

in 56 AM. JUR. 20 Municipal Corporations \$ 234, at 295 n.6 (1971); 68 idl., Schools $\$ 129$. at 459 n.79 (1973); E. McQulLLIN, supra $\$ 12.31$, at $184-85$ n.49.

29. This reading of Sugarman is reinforced by the Court's cryptic comment that it was not ruling out the possibility that

on the basis of an individualized determination, an alien may not be refused, or discharged from, public employment, even on the basis of noncitizenship, if the refusal to hire, or the discharge, rests on legitimate state interests that relate to qualifications for a particular position or to the characteristics of the employec. Id. at $646-47$.

One might attempt to narrow Sugarman by pointing to the fact that it anchored the right of states to control the qualifications of officers and voters in the text of the Tenth Amendment and Article IV, $\$ 4$. See 413 U.S. at 648. But the states' interest in political socialization, if equally essential to effective government, could be given the very same textual support.

30. 413 U.S. 717 (1973).

31. The plaintiff had lived in Connecticut for five years. She was eligible for naturalization, but had taken no steps toward becoming a citizen. Id. at 718 . The Connecticut supreme court upheld the exclusion. In re Fre Le Poole Griffiths, I62 Conn. 249, 294 A.2d 281 (1972).

32. 413 U.S. at 721, quoting McLaughlin v. Florida, 379 U.S. 184, 196 (1964); cf. 413 U.S. at 730 (Burger, C.J., dissenting). See note 15 supra.

33. 413 U.S. at 724 . 
political process as to make him a formulator of government policy."34

On its face, Griffiths suggests that the Sugarman exception will be narrowly defined. However, the nature of the bar committee's argument in Griffiths may limit the reach of the decision. The bar committee relied heavily upon a lawyer's status as an officer of the court, attempting to analogize an attorney's role to regular public office. ${ }^{35}$ The Court in Griffiths clearly held that the lawyer is not within the excepted area of official governmental positions closely related to the political community, ${ }^{36}$ but the opinion fails to illuminate the proper mode of analysis for determining whether other state-licensed positions which cannot be characterized as official might fall within that exception.

\section{Perkins v. Smith}

In view of Graham's rejection of the "special public interest" rationale and Sugarman's definition of the excepted area, a state's justification for alien discrimination must apparently shift from economic to political interests.": An important example of successful reliance on

\footnotetext{
34. Id. at 729 .

35. Id. at 723-25, 727-29; Brief for Appellee at 19-21.

36. Lawyers do indeed occupy professional positions of responsibility and influence

that impose on them duties correlative with their right of access to the courts. . .

Yet, they are not officials of government by virtue of their being lawyers. 413 U.S. at 729 .
}

37. The "excepted area" allowed by Sugarman and Griffiths for state discrimination against aliens is probably not narrowed by any preemptive effect of the federal government's power to regulate immigration and naturalization. Sugarman and Griffiths did not formally reach any question of precmption, as the civil service and bar committce restrictions were voided on equal protection grounds. Sugarman v. Dougall, 413 U.S. 638, 646 (1973); In re Griffiths, 413 U.S. 717, 718 n.3 (1973). However, the Court's explicit recognition of the excepted area in Sugarman seems to imply that once a state has satisfied the standards of equal protection, it will have no difficulty in meeting the challenge of the supremacy clause.

So long as the states sought to justify broad exclusion of aliens from employment on the basis of the state's "special public interest" in preserving employment for state citizens, the conflict with federal power was potentially more acute. Under the Immigration and Naturalization Act, the admission of some aliens is dependent on an assessment by the Secretary of Labor of the labor market conditions in the alien's field of employment. 8 U.S.C. $\$ 1182($ a)(14) $(1970)$ (aliens seeking entry "for the purpose of performing skilled or unskilled labor" are excluded unless the Secretary of Labor determines that "there are not stfficient workers in the United States who are able, willing, qualified, and available at the time of application ... and at the place to which the alien is destined to perform such skilled or unskilled labor"). Reliance by a state on the "special public interest" rationale involved a conflicting conclusion that employment in the state was needed for state citizens. In addition, what the Truax Court said in striking down a broad state-imposed restriction of aliens' private cmployment may apply as well to broad restrictions of statc and municipal employment:

The assertion of an authority to deny to aliens the opportunity of earning a live-

lihood when Iawfully admitted to the State would be tantamount to the assertion of the right to deny them entrance and abode, for in ordinary cases they cannot 
political interests to uphold a restrictive statute is Perkins $v$. Smith ${ }^{38}$ decided by a three-judge district court in Maryland and now on appeal. Perkins concerned the exclusion of aliens from service on state and federal juries, an exclusion imposed respectively by state and federal statutes.

The Perkins court sustained the exclusion, holding that a jury's largely unreviewable role as the arbiter of factual issues in criminal and civil cases made it a critical decisionmaking body, "one of the institutions at the heart of our system of government." 30 Citizenship was necessary for effective performance as a juror because aliens, as a class, were less "conversant with the social and political institutions of the society" and with the "nuances of local tradition and language." In addition, an alien's foreign allegiance might distort the way he or she chose to apply the laws. ${ }^{40}$ Since any independent attempt at ascertaining loyalty would undercut existing naturalization procedures, the use of citizenship as a gauge of allegiance was "compelled by circumstances." 11

live where they cannot work. And, if such a policy were permissible, the practical result would be that those lawfully admitted to the country under the authority of the acts of Congress . . . would be segregated in such of the States as chose to offer hospitality.

Truax v. Raich, 239 U.S. 33, 42 (1915).

38. 370 F. Supp. 134 (D. Md. 1974), appeal docketed, 43 U.S.L.W. 3001 (U.S. June 21, 1974).

39. $370 \mathrm{~F}$. Supp. at 137 .

40. A juror "who lacked any concern for the fairncss of the outcome could screrely obstruct or distort the course of justice." $I d$. at 138. Indeed, a "single persuasive and unprincipled juror could even direct the course of justice into channels deliberately chosen for their deleterious effect on this country." Id. The fact that Perkins deals with what is arguably a political right and not with economic discrimination secms significant to the validation of the restriction. One can view jury service as a political right in that the jury, by utilizing its power of nullification, can modify the substantive law passed by the legislature. Thus, one can argue that restricting an alien's right to serve on a jury is merely a recognition of "a State's constitutional responsibility for the establishment and operation of its own government ..." Sugarman v. Dougall, 413 U.S. 634,648 (1973).

41. Judge Winter, in his concurrence, differed with the majority by finding that there were "less drastic means" of ensuring that alien jurors were fluent in English and familiar with American laws and institutions; nonetheless Wvinter strongly agreed that allegiance and "commitment" to the United States were fundamental to a juror's qualification. $370 \mathrm{~F}$. Supp. at 140 . "Citizens, as a rule, harbor positive feelings toward their sovereign and possess a sense of identity with their fellow citizens." Id. at 141 . Where American law "resolves a question of public policy" or "defin[es] interpersonal relationships" differently than the law of an alien's own country, it is not unreasonable to believe that resident aliens may be likely to permit their positive feelings toward their foreign sovereigns and their sense of identity to their fellowcountrymen to impair their commitment to the enforcement and application of American law in those situations ....

Id. In addition, native-born and naturalized jurors who are eligible to vote and run for public office "have, at least theoretically, some influence upon the content of the laws" and would reasonably be expected to "have a greater commitment to their proper application and enforcement than those lacking such influence." And of course such 
Perkins, recently echoed by a Fifth Circuit decision in United States v. Gordon-Nikkar, ${ }^{42}$ has an important bearing on an alien's right to teach because it establishes that at least some state positions which are not high-level governmental appointments may fall within the Sugarman exception. The opinion recognizes that critical functions going " 'to the heart of representative government" " 43 are sometimes delegated to positions outside the upper levels of any governmental or bureaucratic hierarchy. The Perkins court does fit jury service within the explicit language of the Sugarman exception for offices, noting that jurors hold "important nonelective ... judicial positions" " and "participate directly in the execution" of the law. ${ }^{44}$ But Perkins makes no mention of the term "office," and thus puts a more functional gloss on Sugarman's language, judging the bounds of the excepted positions by their actual relationship to the political community.

\section{Teachers and the State's Interest in Education}

In order to place teachers within the Sugarman exception, the states will have to show ${ }^{45}$ a close relationship between education, the teacher,

personal commitment "is not susceptible of objective measurement." Id. at 141. Thus Perkins recognizes that formal allegiance may be important as a signal of the attitude of persons involved in making judgments that depend on an intangible sense of commitment.

42. 518 F.2d 972 (5th Cir. 1975). Gordon-Nikhar concerned the exclusion of aliens from federal juries only. The issue was raised by the motion of a criminal defendant to quash a jury panel on the ground that the exclusion of resident aliens deprived her of the Sixth Amendment right to trial before a jury representative of the community.

The Gordon-Nikhar court noted the Supreme Court's dictum in Carter v. Jury Comm'n, 396 U.S. $320,332(1970)$, that states are "free to confine the selection [of jurors] to citizens ...." 518 F.2d at 976 n.4. But it also relied heavily on Perkins's equal protection analysis:

We agree with the [Perkins] court's conclusion that there was a compelling interest

"in ensuring that persons who serve as jurors are personally committed to the proper

application and enforcement of the laws of the United States" which therefore justifies the exclusion of aliens.

518 F.2d at 976. Though the Gordon-Nikkar decision cited as an additional justification Congress's plenary authority to regulate the entry and residence of aliens, a ground peculiar to federal measures excluding aliens, the court explicitly noted that the Perkins ground was stufficient. Id. at 977 . An interest in ensuring that jurors are committed to the "proper application of the laws" is applicable of course both to state and federal juries.

43. 370 F. Supp. at 137, quoting Sugarman v. Dougall, 413 U.S. 634, 647 (1973).

44. Id., quoting and paraphrasing Sugarman v. Dougall, 413 U.S. 634, 647 (1973).

45. The arguments that follow in the text, which might support the denial of teachex certification to aliens, have not been offered by any state in litigation. Howerer, these arguments are probably the only grounds left for a justification in light of Sugarman v. Dougall and In re Griffiths. The arguments are dubbed the "state's position" throughout the remainder of the Note.

There is only one court decision dealing with the restriction of the alien's right to be certified as a public school teacher. In Miranda v. Nelson, 351 F. Supp. 735 (D. Ariz. 1972), aff'd mem., 413 U.S. 902 (1973), a three-judge district court invalidated both a state constitutional provision which denied aliens the opportunity to be employed in any state, county or municipal job, and a state law enacted under the authority of that 
and the political community. The validity of the restrictions against aliens will depend in the first instance on whether a public school teacher performs functions that are so intimately involved with the maintenance and identity of the political community as to make an alien unsuitable in the part.

Education does have an essential role in forming and preserving the character of the political community. ${ }^{46}$ One primary function of edu-

provision which made aliens ineligible for employment in any public institution, including public schools. 351 F. Supp. at 739-40. The court based its decision on both equal protection and preemption grounds. Id. at 740. The state's only apparent argument in support of the laws was the "special public interest" rationale (see note 16 supra), which had been treated with little sympathy by the Supreme Court Iess than two years earlier in Gralıam v. Richardson, 403 U.S. 365, 372-75 (1971).

While Miranda voided an alien employment restriction grounded on the state's proprietary interest in preserving jobs for its citizens, it sheds little light on the general status of restrictions against alien teachers. For one, Miranda dealt with a broad, imprecise exclusion of aliens from all state employment, including teaching. Thus, while the litigation happened to involve a teacher, the state's argument and the court's analysis did not focus in any way on the special functions of the teacher in political society. Secondly, the case preceded Sugarman and Griffiths; hence the state's justification was not tailored to the standards articulated in those cases. Finally, the fact that Miranda was affirmed without opinion by the Supreme Court limits the precedential value of the case. See Edelman v. Jordon, 415 U.S. 651, 671 (1974) (Summary affirmances which preceded Edelman "obviously are of precedential value . . . Equally obviously, they are not of the same precedential value as would be an opinion of this Court treating the question on the merits"); Fusari v. Steinberg, 419 U.S. 379, 391-92 (1975) (Burger, C.J., concurring) ("When we summarily affirm, without opinion, the judgment of a threejudge District Court we affirm the judgment but not necessarily the reasoning by which it was reached. . . . Indeed, upon fuller consideration of an issue under plenary review, the Court has not hesitated to discard a rule which a line of summary affirmances may appear to have established."); Note, Summary Disposition of Supreme Court Appeals: The Significance of Limited Discretion and $a$ Theory of Limited Precedent, 52 B.U.L. REv. 373 (1972). As a result, Miranda cannot be said to provide much guidance for analyzing a carefully drawn state statute requiring citizenship for teacher certification.

The only other determinations of the constitutionality of statutes denying aliens teaching certificates are the formal opinions of three states' attorneys general. The Attorney General of California found a provision of the California Education Code cxcluding alien teachers to be unconstitutional. 53 Or. CAL. ATT'Y GEN. 63 (1970) (on file with Yale Law Journal). The opinion was based entirely upon the equal protection reasoning of Purdy \& Fitzpatrick $v$. State, 71 Cal. 2d 566, 456 P.2d 645, 79 Cal. Rptr. 77 (1969), where the California supreme court struck down a broad exclusion of aliens from public employment because of the imprecision of the cxclusion. Is in Miranda, the Attorney General's analysis was not peculiar to the teaching profession; hence the opinion provides little guidance for resolving the present problem. The attorneys general of Pennsylrania and New Jersey have also concluded that statutes excluding alien teachers are void. The Attorney General of Pennsylvania, writing prior to Sugarman and Griffilhs, reached the significant conclusion that teaching, like medicine, "is not a central governmental function ..." and hence could not support a citizenship requirement. 3 P.. BuLr. 204 (Jan. 27, 1973). The opinion of the Attorney General of New Jersey relied on Sugarman and Griffiths to find the statute unconstitutionally imprecise. N.J. Att'y Gen. Formal Op. No. 10, Sept. 23, 1974.

For a related challenge to restrictions on granting tenure to alien teachers on a college faculty, see Younus v. Shabat, 336 F. Supp. 1137 (N.D. Ill. 1971).

46. In The Republic, Socrates praises the role of education in determining the character of a political community:

Indeed ... when a state once has a proper start, it grows as a circle would 


\section{Aliens' Right to Teach}

cation is to provide the citizen with intellectual skills sufficient for effective participation in the political system. A second function is to transmit common values, attitudes, and political knowledge.47

\section{A. Literacy and Political Participation}

For a citizen to participate effectively in a political system that relies on the evaluation of ideas and on informed choice, it is important that he possess at least minimal skills of reading and writing. ${ }^{48}$ But the restriction of teacher certification to those qualified to teach reading and writing can more effectively be accomplished by testing all applicants, including aliens, for verbal and written fluency. Exclusion of aliens from teaching positions in the public schools thus is not substantially related to the educational task of ensuring that citizens are literate.

\section{B. Political Socialization}

A more fundamental way in which education affects the political community is in the process of political socialization-the transmission of political knowledge, attitudes, and values from one generation to

grow. Training and education being kept good engender good natures; and good natures holding fast to the good education become even better than those before ... Then to put it shortly, this one thing needful-training and education-is what the overseers of the city must cleave to, and they must take care that it is not corrupted insensibly. They must guard it beyond everything . . . .

Plato, The Republic Book IV, 424B (W. Rouse transl. 1956). The United States has recognized since its inception the importance of public education to the political community. See, e.g., the Ordinance of 1787, art. III, I Stat. $51-52$ n.(a): "Religion, morality, and knowledge, being necessary to good government and the happiness of mankind, schools and the means of education shall forcver be encouraged." One reason frequently suggested for providing public education is its role in nurturing "good" citizenship. See D. Jaros, Socializition to Politics 9.12 (1973); A. Morris, supra note 6, at XIV (1974); Berkman, Students in Court: Free Speech and the Functions of Schooling in America, 40 Harv. Educ. Rev. 567, 569 (1970).

47. These purposes of education often are not differentiated explicitly by the courts. E.g., Brown v. Board of Educ., 347 U.S. 483 , 493 (1954):

Today, education is perhaps the most important function of state and local governments. Compulsory school attendance laws and the great expenditures for cducation both demonstrate our recognition of the importance of education to our democratic society. It is required in the performance of our most basic public responsibilities, even service in the armed forces. It is the very foundation of good citizenship. Today it is a principal instrument in awakening the child to cultural values, in preparing him for later professional training, and in helping him to adjust normally to his environment.

48. The importance of general intellectual skills to political participation has been a primary justification for the promotion of compulsory public education. See, e.g., MINN. Consr. art. VIII, $\$ 1$ :

The stability of a republican form of government depending mainly upon the intelligence of the people, it shall be the duty of the legislature to establish a gencral and uniform system of public schools.

See In re Shinn, 195 Cal. App. 2d 683, 686, 16 Cal. Rptr. 165, 168 (1961) (dictum). Educa- 
another. ${ }^{49}$ This shaping of political culture can be critical to the character and stability of the political community, for each new generation "emerges upon the political scene as a tabula rasa ... upon which a political system must seek to imprint its image . . . if it is to persist in some form."

With the family and the peer group, the school is recognized as a crucial agent of political socialization. ${ }^{51} \mathrm{~A}$ teacher's role in the process of political and cultural learning becomes critical because a teacher is quite often the first nonfamilial spokesman of society that a child regularly encounters, and functions in the classroom as a model for

tion seems to be positively correlated with various indices of political participation, such as following politics and election campaigns, engaging in political discussions, belonging to voluntary organizations, and believing oneself capable of influencing the government. G. Almond \& S. Verba, The Givic Culture 317-18 (1965). Of course, such correlation does not establish that literacy is the cause of or prerequisite to political participation.

49. Fred I. Greenstein, a leading sociologist, has defined political socialization as follows:

Narrowly conceived, political socialization is the deliberate inculcation of political information, values and practices by instructional agents who have been formally charged with this responsibility. A broader conception would encompass all political learning, formal and informal, deliberate and unplanned, at every stage of the life cycle, including not only explicitly political learning but also nominally nonpolitical learning that affects political behavior, such as the learning of politically relevant social attitudes and the acquisition of politically relevant personality characteristics.

Greenstein, Political Socialization, 14 INT'L ENcycro. OF THE Social Sct. 551 (1968). See Easton \& Hess, The Child's Political World, 6 Midwest J. OF Pol. Scr. 229, 230 (1962).

50. Easton \& Hess, supra note 49, at 232. See Greenstein, supra note 49, at 551.

51. On the role of the school in the political socialization process, see Education AND Political Development (J. Coleman ed. 1965); R. Dawson \& K. Prewitr, Political. Socialization (1969); D. Easton \& J. Dennis, Children in the Politicil Sistem: Origins of Political Legitmacy (1969); R. Hess \& J. Torney, The Development of Political Attitudes in Childrex (.Anchor Books 1968); M. Jennings \& R. Niem, The Political Character of Adolescence (1974); R. Merelman, Political Socialization and Educational Climates (1971); C. Merriam, The Making of Citizens (1931); $c f$. Tapp \& Levine, Legal Socialization: Strategies for an Ethical Legality, 27 STAN. L. Rev. 1 (1974).

Indeed because the school is the only major agent of the process subject to formal control and direction by the community, some commentators view it as the most inportant means of introducing a child to the political system. Sce R. Hess \& J. ToRNEY, supra at 120; Greenstein, supra note 49, at 553-54. The school deals with children throughout impressionable and formative periods of development and is instrumental in conveying early concrete perceptions of the political institutions, values, and attitudes upon which the community is based. R. Diwson \& K. PREwIT, supra at 178. Justice Douglas was quite likely correct in describing the school as the "cradle of our democracy." Adler v. Board of Educ., 342 U.S. 485, 508 (1952) (Douglas, J., dissenting).

Dawson and Prewitt have identified several ways in which the public school acts as an agent of political socialization. "Classroom ritual life"-saluting the flag, patriotic songs, discussion of national heroes and events, and systematic exposure to other symbols and ceremonies-may produce an attachment to the nation and its political values and institutions. R. DAwson \& K. Prewitr, supra at 155-58. A second major instrument of political socialization is the school curriculum. In deciding on the subjects which are to be taught and the materials to be used, the school system consciously attempts to provide the student with formal political knowledge. Id. at 147-55. 
acceptable behavior and social attitudes. ${ }^{52}$ This special task of the teacher could place his or her employment within the excepted area recognized by Sugarman for functions essential to a representative political community. ${ }^{53}$ The premise of the discrimination against aliens would be that an alien, who often has not been fully exposed to American political culture, cannot serve as effectively as the citizen as an agent of political socialization. ${ }^{5 *}$

To examine the validity of that premise, it may be helpful to use the models suggested by Robert Hess and Judith Torney ${ }^{55}$ to describe the ways in which a teacher influences the political orientation of his or her students.

52. [F]or the child the teacher represents an authoritative spokesman of socicty. The teacher is often the first model of political authority the beginning student encounters. How new this kind of authority is to a child can be seen by comparing the parent and the teacher. When a child responds to his parent as an authority figure, he does not separate the role from the incumbent of the role. . . . The public school teacher as an authority figure, on the other hand, is much more like a political authority. The child learns that the authority role and incumbent of the role are separate factors. ... [H] discovers that rewards and punishments from authorities are affected by identifiable constraints that operate on the particular person in the role. The teacher, like the policeman, president, or mayor, is part of an institutional pattern, a constitutional order.

R. DAwson \& K. Prewitr, supra note 51, at 158. In addition,

attitudes toward achievement, toward change, toward fair play, toward manipulability of the environment, toward cooperation, as well as toward obedience and competitiveness, can be shaped by the culture of the classroom. . . . [S] uch components of one's world have important "spill-over" effects and shape political outlooks.

Id. at 165 .

The courts have recognized the extraordinary responsibility that our society places on the teacher. See, e.g., Shelton v. Tucker, 364 U.S. 479, 485 (1960), quoting Adler v. Board of Educ., 342 U.S. 485, 493 (1952) ("A teacher works in a sensitive area in a schoolroom. There he shapes the attitude of young minds towards the society in which they live. In this, the state has a vital concern." ") Justice Frankfurter decribed teachers as "the priests of our democracy" and emphasized their "special task" in society which must be fulfilled "by precept and practice." Wieman v. Updegraff, 344 U.S. 183, 196 (1952) (Frankfurter, J., concurring).

53. The states would have to show that a purpose of the discriminatory statutes was to ensure effective political socialization. They might point to provisions in their educational laws concerned with the promotion of good citizenship. For example the state of Washington might point to the following rather straitlaced provision:

No person, whose certificate or permit authorizing him to teach in the common schools of this state has been revoked due to his failure to endeavor to impress on the minds of his pupils the principles of patriotism, or to train them up to the true comprehension of the rights, duty and dignity of American citizenship, shall be permitted to teach in any common school in this state.

WASH. REv. CODE $\$ 28 A .67 .030$ (1970).

54. See, e.g., R. DAwson \& K. PREwITT, supra note 51, at 160-61 :

One major reason why teachers operate so effectively in this connection [as conveyors of consensus values] is that they are products of the same political socialization for which they serve as agents. Teachers generally do not need to be taught to laud the virtues of the nation. Their own political selves have been shaped in accordance with the very consensus values they now transmit.

55. R. HESS \& J. TORNEY, supra note 5I, at 22-26. 


\section{Identification with the Teacher}

The "identification" model emphasizes imitation by the student of the behavior and attitudes of the teacher. ${ }^{56}$ In exchanges with the student, a teacher inevitably conveys many of his or her own cultural attitudes, influencing political orientation well beyond the formal curriculum and any conscious effort to impart political information. ${ }^{57}$ The states' concern would be that regardless of any conscious attempt by an alien teacher to avoid affecting the political outlook of students, they will be so influenced. Thus an alien teacher would "distort" the process of socialization, if one accepts the premise that aliens are likely to have political and cultural attitudes different from those of citizens that cannot feasibly or constitutionally be "tested for" as part of the certification process. A second concern might be that an alien, who by definition has a formal foreign political allegiance, may impede the usual socialization of pupils to a domestic political allegiance. This concern for undivided allegiance underlies statutes which allow an alien to teach once he or she has declared an intention to become a United States citizen. ${ }^{5 s}$

\section{Acquiring Political Knowledge}

An attempt to exclude aliens from public school teaching could also rely on the "accumulation" model of political socialization. This model views political socialization as proceeding by an accretion of political knowledge and information. Unlike the identification model, accumulation concerns the conscious, direct, and formal transfer of information. 59

The argument that an alien teacher is less effective than a citizen in fulfilling this part of political socialization might be two-fold. First, it could be argued that an alien is not sufficiently conversant with the American political system to effectively teach formal aspects of political culture. Second, there is some evidence that civic education is more successful when the formal content of the curriculum is in harmony with the political orientation of the teacher, so that his or her more casual statements about politics and government are consonant with the formal curriculum. ${ }^{\text {oo }}$ Thus, the states could assert that even if the

56. Id. at 24 .

57. For example, the manner in which the class is conducted, whether authoritarian or democratic, may affect the political views of the students. R. D.wSon \& $\mathrm{K}$. Prewitr, supra note 51 , at $165-67$.

58. For a listing of such statutes, see note 11 supra.

59. R. Hess \& J. TORNEY, supra note 51, at 23; Greenstein, supra note 49, at 551 .

60. See R. Dawson \& K. Prewitr, supra note 51, at 149-50; R. Hess \& J. ToRner, supra note 51, at 127-32; Litt, Civic Education, Community Norms and Political In- 
alien has the requisite knowledge of the subject matter, his or her presentation of the material will likely be less effective than that of the citizen.

\section{An Alien's Right to Teach}

In view of the narrowing of the field of permissible discrimination against aliens in Sugarman and Griffiths, the argument in support of denying teacher certification to aliens must rest principally on the state's assertion of a compelling interest in using its public schools for political socialization. The courts may view the statutory requirements for naturalization-including five years' residence and demonstrated familiarity with American history and government-as support for the proposition that an alien is not sufficiently conversant with American mores and political institutions to act as an effective agent of political socialization in the public schools. ${ }^{61}$ As Justice Rehnquist argued in his dissent in Sugarman, the major goal of the naturalization process is to ensure that aliens demonstrate the familiarity with American culture which citizens as a class are presumed to gain from "formal education and basic social contact." 62 The courts also may look to the rationale used in Perkins and in Gordon-Nikkar, where aliens were excluded from jury service because they were assumed to be less familiar with national and local institutions.

Yet the state's interest must be deemed sufficient to justify a suspect classification. One consideration that might demote a legitimate state interest from status as a compelling one is the First Amendment problem raised in the state's attempt to control the process of socialization. In addition, the means used by the state to advance the interest may not be sufficiently precise.

Because the teacher's role in the process of socialization encompasses

doctrination, 28 AM. Soc. Rev. 69, 73, 74 (1963). Litt studicd civic education in three Boston high schools, in upper middle class, lower middle class, and working class neighborhoods. He concluded that the influence of the formal civics curriculum was greatest when it was congruent with the attitudes towards government and political participation generally held in the community.

61. 8 U.S.C. $\$ 1423(1970)$ provides that an alien seeking naturalization must show "an understanding of the English language" and "a knowledge and understanding of the fundamentals of the history, and of the principles and form of government, of the United States." The House Judiciary commented on this provision:

Through the system of citizenship classes sponsored by the Immigration and Naturalization Service and the local school system, the alien is aided in preparing himself for citizenship, and every effort is made to give him fundamental and uniform knowledge of our political and social structure.

H.R. REP. No. 1365, 82d Cong., 2d Sess. 78 (1952).

62. Sugarman v. Dougall, 413 U.S. 634, 659 (1973) (Rehnquist, J., dissenting from the majority in both Sugarman and In re Griffiths, 413 U.S. 717 (1973)). 
the distinct phenomena of identification and direct political teaching; the character of the state's interest should be assessed in light of each.

\section{A. First Amendment Considerations}

In educating the young in citizenship, there should be unusually scrupulous attention to the First Amendment," "if we are not to strangle the free mind at its source and teach youth to discount important principles of our government as mere platitudes." ${ }^{64}$ In evaluating the requirements of the First Amendment in the present context, ${ }^{65}$ a distinction may be made between attempts by the state to exclude from its public schools political influences deemed to be unfavorable and efforts to include socializing influences that transfer political information thought to be important.

\section{Identification with the Teacher}

A fundamental value which lies at the core of the political system is freedom of speech and thought. It would be ironic indeed for states concerned with the education of a critical citizenry to exclude influences from the public schools that might cast doubt on the unthinking acceptance of generally held political values and attitudes. Yet, at the heart of the argument based on the identification model is the fear that the unconscious transfer of foreign political and cultural values will "distort" the political socialization process. Denying teacher certification to aliens on this ground necessarily amounts to an effort to exclude "unfavorable" influences from the process of political socialization.

In Pierce v. Society of Sisters, in recognizing parents' right to have their children educated in private schools, the Court rejected the state's use of the public schools to "standardize" the next generation of citizens. ${ }^{66}$ Similarly, in Meyer v. Nebraska, ${ }^{67}$ the Court invalidated

63. The rights guaranteed by the First Amendment, including freedom of speech, are protected against state action by the due process clause of the Fourteenth Amendment. Fiske v. Kansas, 274 U.S. 380 (1927); Gitlow v. New York, 268 U.S. 652 (1925); Duncaul v. Louisiana, $39 \mathrm{I}$ U.S. 145, 148 (1968). Thus they are applicable to state regulation of the public schools.

64. West Va. Bd. of Educ. v. Barnette, 319 U.S. 624, 637 (1943).

65. The arguments made below in regard to the limits placed by the First Amendment on a state's interest in political socialization in the public schools apply a fortiori to any attempt to require citizenship for teaching in nompublic schools.

66. Pierce v. Society of Sisters, 268 U.S. 510,535 (1925) (emphasis added):

The fundamental theory of liberty upon which all governments in this Union repose excludes any general power of the State to standardize its children by forcing them to accept instruction from public teachers only. The child is not the mere creature of the State....

67. 262 U.S. 390 (1923). Meyer preceded the express incorporation of First Amendment rights into the Fourteenth Amendment. 
a Nebraska statute prohibiting the teaching of foreign languages in the public schools, spurning Nebraska's contention that allowing foreignborn students to be taught their native language would "inculcate in them the ideas and sentiments foreign to the best interests of this country." 08 Interpreting Meyer in a later decision, the Court has asserted that a state may not conduct its schools to deliberately "foster a homogeneous people." ${ }^{0}$ The Court's strong support for academic freedom ${ }^{70}$ and careful restriction of loyalty oaths for teachers ${ }^{71}$ also reflect the view that the First Amendment will not tolerate laws that "cast a pall of orthodoxy over the classroom."'T2 Rather, students should be exposed to "that robust exchange of ideas which discovers truth 'out of a multitude of tongues, [rather] than through any kind of authoritative selection." "ז3

The exclusion of alien teachers out of a fear of the unconscious transfer of foreign attitudes and values is an effort to standardize and

68. Id. at 398. See Farrington v. Tokushige, 273 U.S. 284 (1927) (invalidating restrictions on foreign language schools in the Territory of Hawaii).

69. Tinker v. Des Moines Independent Community School Dist., 393 U.S. 503, 511 (1969). In Tinker, the Court restrained the defendant school district, on First Amendment grounds, from disciplining two high school students for wearing black arm bands protesting the Viet Nam War in violation of a school regulation. In citing Meyer, the Court noted that the decision "expressed this Nation's repudiation of the principle that a state might so conduct its schools as to "foster a homogeneous people." Id.

70. See, e.g., Keyishian v. Board of Regents, 385 U.S. 589 (1967), invalidating New York State's Feinberg Law. The law required the state board of regents to issue regulations for the disqualification or removal of faculty in the state educational system who were "disloyal" and to make a list of "subversive" organizations, membership in which would constitute prima facie evidence of disqualification for employment. The Supreme Court found the statute and implementing regulations invalid on First Amendment grounds and stressed the value of academic frecdom: "Our Nation is deeply committed to safeguarding academic freedom, which is of transcendant value to all of us ...." Id. at 603 .

In Sweezy v. New Hampshire, 354 U.S. 231 (1957), the Court reversed a contempt citation against a university professor who refused to testify about the content of his lectures in an investigation conducted by the state attorney general. While the Court based its holding on the vagueness of the New Hampshire statute authorizing the attorney general to conduct such an inquiry, the Cout also emphasized the importance of academic freedom:

No one should underestimate the vital role in a democracy that is played by those who guide and train our youth. To impose any strait jacket upon the intellectual

leaders in our colleges and universities would imperil the future of our Nation. Id. at 250. See Developments in the Law-Academic Freedom, 81 HARv. L. REv. 1045 (1968).

71. The Supreme Court has consistently held the statutes requiring such oaths to be orerbroad and vague. See, e.g., Elfbrandt v. Russell, 384 U.S. 11 (1966); Baggett v. Bullit, 377 U.S. 360 (1961); Cramp v. Board of Public Instruction, 368 U.S. 278 (1961); cf. Kcyishian v. Board of Regents, 385 U.S. 589 (1967). See Van Alstyne, The Constitutional Rights of Teachers and Professors, 1970 DukE L.J. 841; Note, Academic Freedom in the Public Schools: The Right to Teach, 48 N.Y.U.L. REv. 1176 (1973).

72. Keyishian v. Board of Regents, 385 U.S. 589, 603 (1967).

73. Id. at 603, quoting United States v. Associated Press, 52 F. Supp. 362, 372 (S.D.N.Y. 1943). 
homogenize the process of political socialization. As such, it is inconsistent with First Amendment values. Though there are some difficulties with arguing that the citizenship requirements themselves violate the First Amendment, ${ }^{\text {it }}$ the inconsistency may well render illegitimate any state interest based on the identification model of political socialization. At the very least, such a justification is sufficiently opposed to the spirit of the First Amendment to be properly disqualified from status as a compelling interest. ${ }^{i j}$

\section{Acquiring Political Information}

The accumulation model of socialization is concerned not with the unconscious transfer of values and attitudes, but rather with the direct and formal imparting of political information. The states would assert that the alien teacher performs this function less effectively than the citizen for two reasons. First, aliens, as a class, are presumed to be less conversant with the political information to be transferred. Second, because the presentation of this material is more effective when the content is in harmony with the political orientation of the teacher, aliens may be less successful in their presentation even if they have the requisite knowledge. This aspect of political socialization focuses not so much on the exclusion of unfavorable influences as on the affirmative task of conveying political information.

74. The difficulties are several. For one, there is no explicit speech or line of thought being repressed. Secondly, and more significantly, a decision invalidating these laws as violative of the First Amendment would call into question all efforts at political socialization. For in a real sense, all political socialization involves an imposition of values.

75. The Supreme Court used analogous reasoning in Williams v. Rhodes, 393 U.S. 23 (1968). In Williams, the Court invalidated several Ohio election laws that made it virtually impossible for any political party other than the Republicans or Democrats to be placed on the state ballot used to choose electors pledged to candidates for the presidency and vice presidency. $I d$. at 24 . Two political parties challenged the statutes on the ground that they denied equal protection to the parties' supporters. The Court found that the questioned statutes "place[d] burdens" on the First Amendment right of freedom of association. $I d$. at 30 . As a result, the Court demanded that Ohio demonstrate a "compelling interest" in order to justify the laws.

In an effort to meet this test, the state asserted that it had a compelling interest in the promotion of a two-party system. However, the Court refused to classify this interest as compelling for purposes of the equal protection analysis because the interest itself was inconsistent with First Amendment values. Justice Black, writing for the Court, stated:

[Ohio] claims that the State may validly promote a two-party system in order to encourage compromise and political stability. The fact is, however, that the Ohio system does not merely favor a "two-party system"; it favors two particular parties ... and in effect tends to give them a complete monopoly. There is, of course, no reason why two parties should retain a permanent monopoly on the right to have people vote for or against them. Competition in ideas and governmental policies is at the core of our electoral process and of the First Amendment freedoms....

Id. at 31-32. 
The legitimacy of the state's concern with the harmonious relationship between the content of the curriculum and the personal political orientation of the teacher is open to question, because of general judicial disfavor for state inquiry into personal political beliefs. However, the Supreme Court has recognized the legitimacy of the state's interest in using its schools for the shaping and preservation of the political community by transfer of important political information. ${ }^{\text {i }}$ Therefore, the state's interest in ensuring that its teachers possess the requisite knowledge of the political system and political institutions would appear to be compelling.

\section{B. Imprecision}

The Supreme Court in Sugarman noted that a statute restricting alien employment must be drawn with great precision, excluding aliens only where necessary to the protection of the state's compelling

76. Take, for instance, the flag salute cases. In Minersville School Dist. v. Gobitis, 310 U.S. 586 (1940), the Supreme Court upheld a state regulation requiring that pupils in public school participate in a daily flag salute ceremony. Justice Frankfurter, writing for the Court, emphasized the state's interest in using its schools for the promotion and presersation of the political community.

The ultimate foundation of a free society is the binding tie of cohesive sentiment. Such a sentiment is fostered by all those agencies of the mind and spirit which may scrve to gather up the traditions of a people, transmit them from generation to generation, and thereby create that continuity of a treasured common life which constitutes a civilization.

...

... The influences which help toward a common feeling for the common country are manifold. Some may seem harsh and others no doubt are foolish. Surely, however, the end is legitimate.

Id. at 596, 598. It was for this reason that the Court would not "exercise censorship over the conviction of legislatures that a particular program or exercise will best promote in the minds of children who attend the common schools an attachment to the institutions of their country." Id. at 599.

In West Va. Bd. of Educ. v. Barnette, 319 U.S. 624 (1943), the Court overruled Gobitis on the question of compelling students to salute the flag. However, the Court seemed to question only the means by which the state sought to use its schools for political socialization and not the legitimacy of the end itself. Justice Jackson, writing for the Court, asserted:

As the present Chief Justice [Stone] said in dissent in the Gobitis case, the State may "require teaching by instruction and study of all in our history and in the structure and organization of our government, including the guaranties of civil liberty, which tend to inspire patriotism and love of country." 310 U.S. at 604 . Here, however, we are dealing with a compulsion of students to declare a belief. They are not merely made acquainted with the flag salute so that they may be informed as to what it is or even what it means. The issue here is whether this slow and easily neglected route to aroused loyalties constitutionally may be short cut by substituting a compulsory salute and slogan.

Id. at 631 (footnotes omitted). The courts traditionally have been reluctant to interfere extensively with the curriculum of the public schools, emphasizing that they are illequipped to substitute for school boards or legislatures in the determination of what is essential to a successful program of compulsory public education. See, e.g., Wisconsin v. Yoder, 106 U.S. 205, 234 (1972); Epperson v. Arkansas, 393 U.S. 97, 104 (1968); Meyer v. 
interest. ${ }^{i 7}$ Therefore, even if one concedes that the state's interest in the accumulation aspect of political socialization is compelling and that it places public school teaching within the Sugarman exception, the analysis still is not complete. Discriminatory state statutes, as presently enacted, generally exclude aliens from all teaching positions in the public schools, without regard to grade level or subject matter. There are several more precise and "less drastic means" 78 for advancing the state's interest.

The statutes in their present form exclude alien teachers at all grade levels. While the process of political socialization continues throughout life, the most critical period seems to be between the ages of three and $13 .{ }^{79}$ The state's interest in political socialization, though arguably compelling in elementary school education, thus wanes considerably in the high school. The varying interest of the state in primary and secondary education was recognized in Wisconsin $v$. Yoder, ${ }^{80}$ where the Court held that a state could not compel the attendance of Amish children in the public schools beyond the eighth grade. One commentator concludes that this decision struck a severe blow to any state interest in secondary education..$^{81}$ As such, the precision demanded by use of a suspect classification would limit the permissible exclusion of alien teachers to the elementary school level.

If the state's compelling interest in political socialization is limited to the formal transfer of political information, it would also appear that the exclusion of alien teachers must be limited to subjects in which

Nebraska, 262 U.S. 390, 402 (1922.) Though the reluctance of the courts to intervene in public school operations has been waning (see, e.g., Goss v. Lopez, 419 U.S. 565 (1974); Tinker v. Des Moines Independent Community School Dist., 393 U.S. 503 (1969)), one still might expect considerable deference as to the content of curriculum.

77. See p. 95 \& note 23 supra.

78. See note 15 supra.

79. See, e.g., R. Hess \& J. ToRney, supra note 51, at 131; M. Jennings \& R. Niemi, supra note 51, at 181-206; Easton \& Hess, supra note 49, at 236; Greenstein, supra note 49 , at 554. These works suggest that much of one's basic political socialization occurs before the end of the elementary school years. This, of course, is not to suggest that political attitudes and orientation do not change after the eighth grade, but only that the state's interest is stronger in primary education.

80. 406 U.S. 205,227 (1972) ("[T] here is at best a speculative gain, in terms of mecting the duties of citizenship, from an additional one or two years of compulsory formal education [beyond the eighth grade].")

81. Kurland, The Supreme Coutr, Compulsory Education, and the First Amendment's Religious Clauses, 75 W. VA. L. REv. 213, $229-30$ (1973). It should be noted that even on the elementary school level, the state's interest in public education may be outweighed by other concerns. Thus, in 1925, in Pierce v. Society of Sisters, 268 U.S. 510, the Court held that the state's interest in public education must yield to the parents right to provide for equivalent education in private schools. The Court affirmed an injunction restraining the state of Oregon from requiring compulsory attendance at public schools. Similarly, in concluding that teaching is not a "central governmental function" and hence unable to support a citizenship requirement, the Attorncy General of Pennsylvania noted that teaching is often "cntrusted to private institutions." 3 PA. BuLL. 201 (Jan. 27, 1973). 
this information is most central, such as civics and history. ${ }^{22}$ Therefore, the statutes in their present form are overbroad in a second way, for they exclude alien teachers regardless of the subject matter they are to teach. Since, at the elementary school level, one teacher most often teaches all subjects, if the state wishes to exclude aliens it should be required to create specialist positions for teachers of history and civics. Indeed, the state can probably protect its interest in the teaching of these subjects by testing the competence of individual teachers at the certification stage, ${ }^{83}$ thus invalidating any automatic exclusion of aliens from public school teaching.

82. Even in these subjects there is some controversy as to the impact of the teacher on the political orientation of his students. See Jennings, Ehman \& Niemi, Social Studies Teachers and Their Pupils, in M. JENnINGs \& R. NiEMI, supra note 51, at 207.

83. All states require teachers to attend an accredited teacher education institution to be cligible for certification. See T. STINNET, supra note 7, at 35 . This alone may make unnecessary the exclusion of alien teachers from the public schools, for it ensures an opportunity for the state to monitor competency. 